\title{
Migration of Willow Ptarmigan in Arctic Alaska ${ }^{1}$
}

\author{
LAURENCE IRVING, GEORGE C. WEST, \\ LEONARD J. PEYTON, AND SIMON PANEAK ${ }^{2}$
}

\begin{abstract}
Willow ptarmigan (Lagopus lagopus) migrate southward in autumn through Anaktuvuk Pass in the Brooks Range of Alaska and move northward in late winter to their principal nesting grounds on the arctic slope. In the morphologically homogeneous population four categories were distinguished-adult and juvenile males, adult and juvenile females-month by month at three localities. Adult males preponderate in winter in their northern range, a large proportion of juvenile males winter at Anaktuvuk, and females preponderate in the southern wintering range. Each agesex category moves according to its own program and flocks change composition.
\end{abstract}

RÉSUMÉ. Migration du lagopède des saules dans l'Alaska arctique. À l'automne, le lagopède des saules (Lagopus lagopus) migre vers le sud par la passe d'Anaktuvuk, dans la chaine de Brooks, Alaska; à la fin de l'hiver, il revient vers le nord jusqu'à ses principaux terrains de nichée situés sur le versant arctique. Dans une population morphologiquement domogène, on a distingué, mois par mois, en trois localités différentes, quatre catégories h'individus - mâles adultes, mâles juvéniles, femelles adultes et femelles juvéniles. En diver, les mâles adultes l'emportent en nombre dans le nord de l'aire de migration: une hrande proportion des mâles juvéniles hivernent à Anaktuvuk: les femelles l'emportent gans le sud de l'aire d'hivernage. Chacune de ces catégories d'âge et de sexe se déplace selon son propre programme et la composition des bandes évolue en conséquence.

РЕЗЮМЕ. Миарация белой куропатки в арктической Аляске. Белая куропатка (Lagopus lagopus) мигрирует на юг осенью черев проход Анактувук в хребте Брукса, Аляска, а в конце зимы передвигается к северу на главные гнездилища арктического склона. В морфологически гомогенной популящии различаются четыре категории: взрослые и молодые самцы, и взрослые и молодые самки, наблюдаемые ежемесячно в трех районах. Взрослые самцы преобладают зимой в северных зонах; значительная часть молодых самцов зимуют в Анактувуке, а самки преобладают в южных районах зимовки. Каждая возрастно-половая категория передвигается своим путем, и их стаи меняют свой состав.

Numerous flocks of willow ptarmigan (Lagopus lagopus) are characteristic of the arctic and alpine tree line and the continental tundra of North America and Eurasia. These northern grouse, white in winter (see Frontispiece) and brown with black tail feathers in summer, are familiar to resident northern people and to winter travellers. The orderly action of winter flocks led Eskimos and northern Indians to regard them as organized societies and, in their mythology, to designate them as ptarmigan "people." Important as winter food for the native population, the swift-flying birds are also esteemed as game by sportsmen and as a delicacy in Scandinavian cuisine. The traditional acceptance of the willow ptarmigan as representative of northern winter life led to its designation by the legislature of the Territory

1Publication No. 42, Laboratory of Zoophysiology, Institute of Arctic Biology, University of Alaska.

${ }^{2}$ Resident. Anaktuvuk Pass. Alaska. 
of Alaska as the Alaskan bird, a designation that continues to hold in the Forty-Ninth State. Although so familiar and frequently so abundant, the occasional nature of winter observation has not shown the orderly program that should connect a bird population with the conditions characteristic of changing arctic seasons. However, with help from the hospitable and observant Eskimos of Anaktuvuk Pass we have been fortunate in obtaining an outline of the organized winter movements of a large population of willow ptarmigan as they migrate in arctic Alaska.

In recording the movements of willow ptarmigan through the narrow valley of Anaktuvuk Pass since i 948 , we remarked on an earlier occasion that the regularity of their southward progress before midwinter and the regularity of their later northward movement were characteristic of a migrating population (Irving 1960 ). We suspected that the range of this movement was confined to the region between the Koyukuk Valley in the south and the arctic coast in the north. By examining the flocks at northern, central, and southern localities, we thought that we could obtain a view of the organization of this migratory population that would not be possible elsewhere. The narrow valley through which the migrants pass and the keen observations of the Eskimos at Anaktuvuk have helped us to determine, at least in part, the program of these ptarmigan throughout the winter.

\section{GENERAL VIEW OF THE MIGRATION}

In the village of Anaktuvuk, where soo inland Eskimos settled in I 948, we have been able to join with expert hunters who live in the path of the ptarmigan migration and whose ancestral knowledge of the country extends back for many generations. The inland Eskimos (Nunamiut) still depend mainly upon caribou for subsistence, but in winter they take ptarmigan when caribou are not available. In older times, when caribou could not be found, a few ptarmigan might save a family from starvation, especially as old people and children could take ptarmigan with snares when the hunters were sick or were away. Closely observed phenomena in the migration of ptarmigan are therefore part of the essential ancestral Eskimo knowledge through which we can look back for many years upon ptarmigan migration in the arctic interior, where these formerly nomadic Eskimo people have lived. Simon Paneak, long-time chief of the village council, has recorded the activities of ptarmigan and associated phenomena from his own observations and from those of his neighbours, and his records provide the only existing account of the movements and habits of the birds in the interior of arctic Alaska.

In addition to the observations of Paneak and those recorded by Irvirg ( 1960$)$ at Anaktuvuk $\left(68^{\circ}{ }^{1} 0^{\prime} \mathrm{N} .,{ }_{1} 5^{\circ} 4^{4} 6^{\prime}\right.$ W.), additional observations and collections were made on the breeding grounds in the Colville River Valley, primarily at Umiat $\left(69^{\circ} 24^{\prime} \mathrm{N}\right.$., $152^{\circ} 07^{\prime} \mathrm{W}$. $)$, and in the wintering area south of Anaktuvuk along the John River Valley, principally near Crevice Creek $\left(67^{\circ} 22^{\prime}\right.$ N., $152^{\circ}$ o4 $4^{\prime}$ W. $)$ and Bettles Field on the Koyukuk 


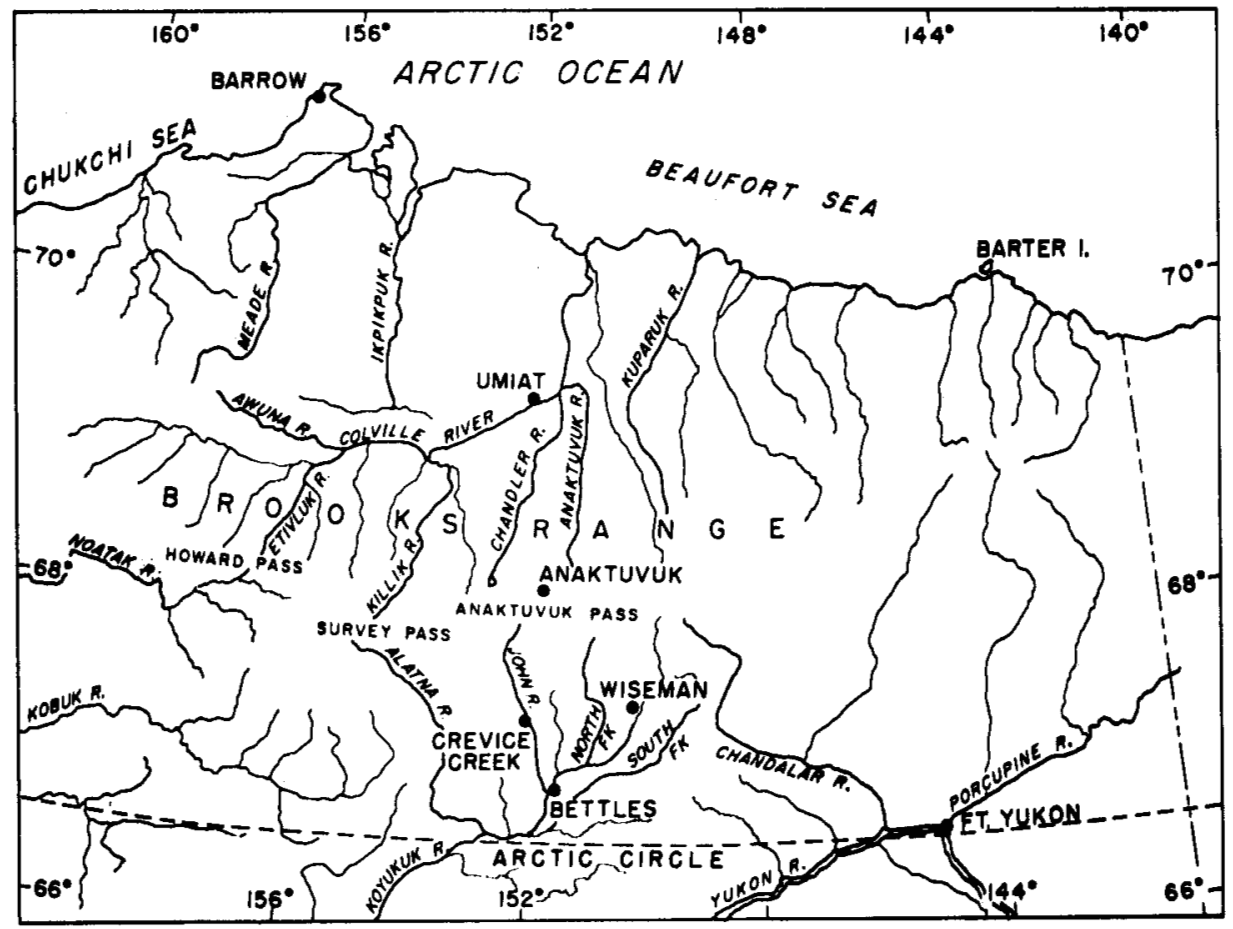

FIG. I. Central and eastern arctic Alaska, showing collecting localities at Umiat, Anaktuvuk Pass, Crevice Creek, and Bettles.

River $\left(66^{\circ} 55^{\prime}\right.$ N., $15^{\circ}{ }^{\circ} 8^{\prime}$ W.), from 1963 to 1965 (Fig. I). Sex was determined by gonad examination. Age was determined by presence (juvenile) or absence (adult) of the bursa of Fabricius until December of the year of hatch. Since it was found that juvenile birds could be accurately distinguished by pigmentation of the ninth primary in 97 per cent of the cases examined, this criterion was used for age determination from January on (West $e t$ al. in press). Collections were usually made by shooting, and large samples were removed from individual flocks so that confidence could be placed in the proportions of sexes and ages of birds in the flock.

Frequency plots of the four age-sex categories in the population were made by computer analysis for each location and for each month of collection. Measurements of wing and tail length, and of body weight revealed that the birds throughout the sampling range were both morphologically homogeneous and normally distributed, and they were thus considered to be from the same biological population (West et al. in press). This assumption was borne out by the fact that the ptarmigan population in the Brooks Range differed significantly from other Alaskan populations.

ANALYSIS OF THE MIGRATORY POPULATION

Willow ptarmigan breed in large numbers from the north slope of the Brooks Range to the arctic coast, with concentrations in the willow bars 
and alder brush along major river valleys such as the Colville. With the onset of winter, flocks are formed from family groups and the southward movement begins late in September. A large number of the birds of the arctic slope traditionally move through Anaktuvuk Pass. Here the patches of low willow, scattered at intervals of one to several miles throughout the John River Valley, provide more than go per cent of the food supply of wintering ptarmigan (West and Meng i 966; Irving et al. I 967). Since the willows form a pathway for the birds that is less than a mile in width, observers at Anaktuvuk can easily watch their movements and estimate the number of birds passing through the area.

In several years, Paneak has daily recorded the number of ptarmigan that he has seen. On 29 April ig6o he estimated that I o, ooo had passed northward before 7:00 A.M. On I May I 960 he saw only a few birds in the vicinity. The following figures summarize his journal estimates of the numbers of ptarmigan that he recorded daily:

$$
\text { September-December }
$$

$$
\begin{aligned}
& \text { I } 960 \\
& \text { I } 96 \text { I } \\
& \text { I } 962 \\
& \text { I } 963 \\
& \text { I } 964
\end{aligned}
$$

$$
\begin{gathered}
\text { January-May } \\
52,000 \\
2 \text { I, 000 } \\
38,000 \\
24,000 \\
24,000
\end{gathered}
$$

From Paneak's estimates and from discussion with other Eskimos in the village, we estimate that in the order of 50,000 ptarmigan move southward and northward through Anaktuvuk Pass annually. The fall migration reaches a peak in mid-October and the population appears to be rather stable in December (Fig. 2). In mid-January and in early February the ptarmigan begin to move northward, but in March the movement subsides, only to commence again by early April. The peak northward move-

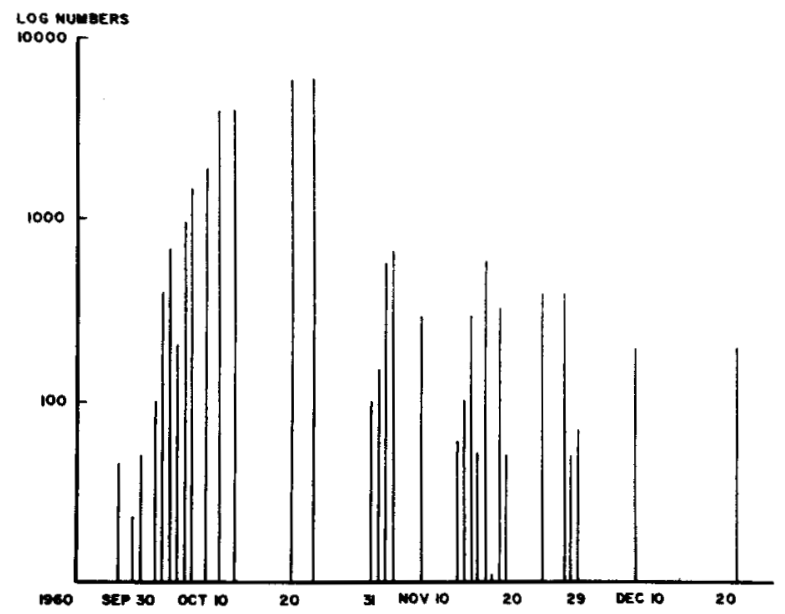

FIG. 2. Numbers of willow ptarmigan recorded at Anaktuvuk Pass in autumn i 960 . 


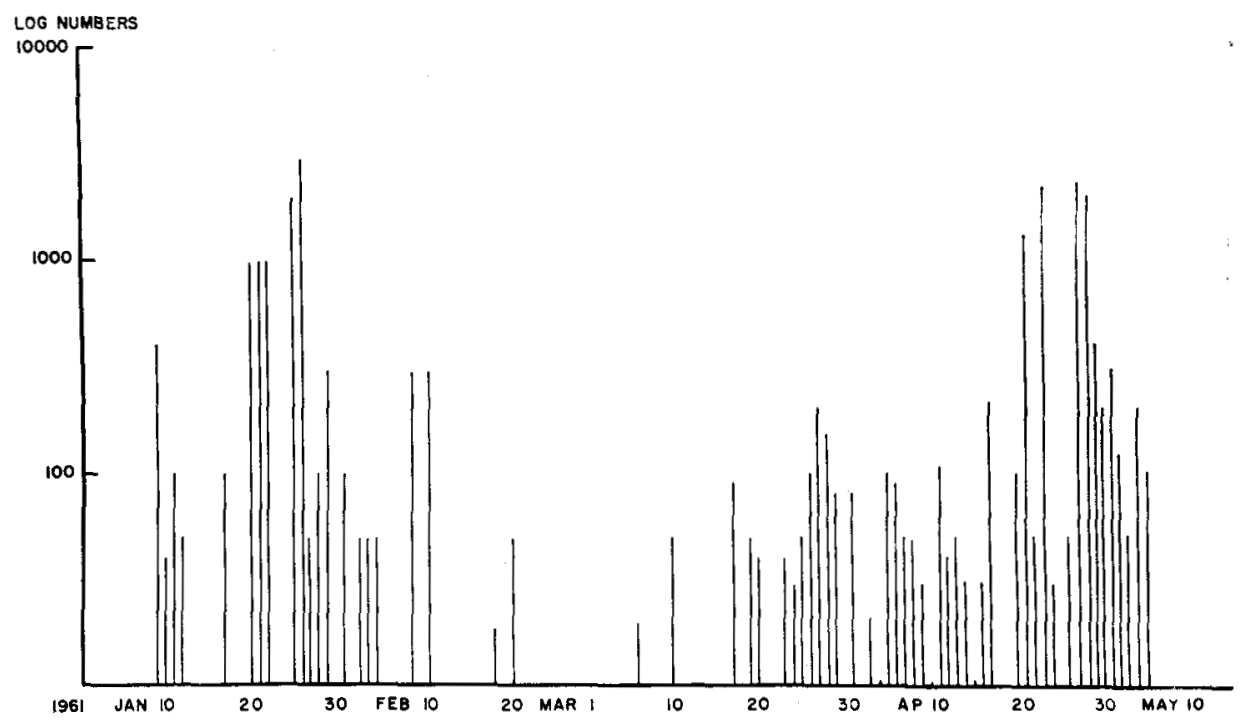

FIG. 3. Numbers of willow ptarmigan recorded at Anaktuvuk Pass in spring i 96 I.

ment occurs in late April, and by early May few birds remain to nest at Anaktuvuk (Fig. 3). The regularity of the two distinct northward migrations of ptarmigan is confirmed by the fact that the Nunamiut have separate names for each migration ("Iklit" and "Kadgiliotit") and relate events which have occurred in late winter to the two periods of ptarmigan activity (Irving 1960). From the Pass, ptarmigan move southward as far as the Koyukuk River. At Publituk Creek, about 35 miles south of Anaktuvuk, the spruce forest begins and birds are harder to observe. However, collections at Crevice Creek and at Bettles Field show that ptarmigan are present in considerable numbers from November through April, but not in summer. In late winter and again in spring, the ptarmigan move northward through Anaktuvuk Pass and pairs assemble in the breeding areas at the end of May.

\section{COMPOSITION OF THE MIGRATING POPULATION}

At Umiat in September, family groups have formed flocks with the ages and sexes about equally represented (Fig. 4). The young birds still follow the leadership of parents. In October, more and larger flocks are present, parental leadership is no longer evident, and restlessness and movements indicate migration southward. Already in October the proportions by sex and age at Umiat show an accumulation of adult males (which we suspect come from the north) and emigration of juvenile birds and adult females. Winter weather has made collections statistically insignificant from November until March, when adult males predominate, but it appears that little change in flock composition takes place through the winter into May (Fig. 4). 


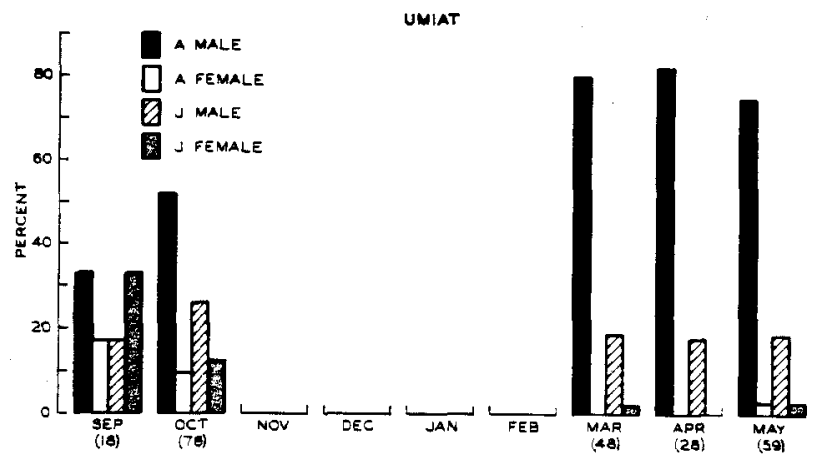

FIG. 4. Proportions by sex and age of willow ptarmigan collected at Umiat, $1963-65$.

In the years of recorded observation at Umiat ( $\left.1963^{-6}\right)_{5}$, we did not encounter in May the migrating hordes that Paneak had once seen crossing northward over the Colville River. (He and his father captured several hundred in nets, enough to load a sled.) By I June males and females were settling in pairs, but in order to observe summer nesting, collections were discontinued and the return of important numbers of the inconspicuous females was not recorded.

The composition of samples from Anaktuvuk (1961-65) suggests a complementary relation to records at Umiat (Fig. 5). The proportion of

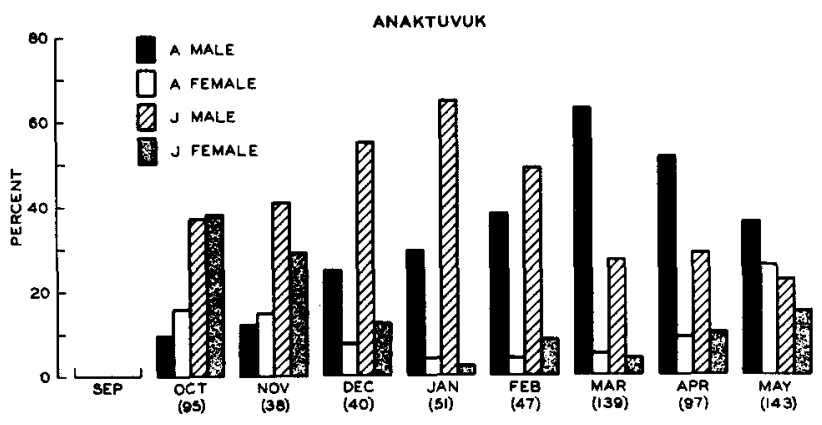

FIG. 5. Proportions by sex and age of willow ptarmigan collected at Anaktuvuk, I $96 \mathrm{I}-65$.

adult males gradually increased until March, as if coming from the north, and then decreased, as if selectively returning northward. The proportion of juvenile males began to increase earlier in autumn and continued to do so until January. Maximal proportion of adult and juvenile males occurred two months apart. Adult and juvenile females diminished to rarity from December into April.

In the southern John River and the Koyukuk valleys, adult males were scarce in winter with somewhat more juvenile males present (Fig. 6). Only in February did adult females exceed juvenile females. In March and April the proportion of juvenile females increased as if they were the last to migrate northward. The scarcity of ptarmigan in April suggests that emigration of the other categories left behind a majority of juvenile females. 


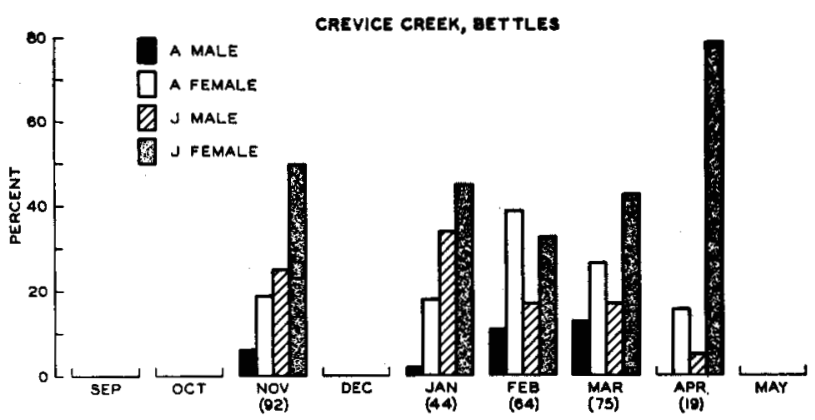

FIG. 6. Proportions by sex and age of willow ptarmigan collected at Crevice Creek and Bettles, 1963-65.

\section{DISCUSSION}

The well-remembered but unrecorded experience of the inland Eskimos in other parts of the Brooks Range indicates that willow ptarmigan migrate southward and northward on a similar time schedule through numerous valleys that run approximately parallel to the Anaktuvuk River. This general view is affirmed with respect to the commonness of a first and second phase of northward migration, the appearance during spring of birds with thinner foot feathering, and other manifestations of similar action of willow ptarmigan throughout the central part of the Brooks Range. Flights eastward and westward are seldom observed in comparison with the predominant north and south movements through each valley. North of the mountains the terrain does not suggest geographical separations in the general nesting area, and we cannot critically estimate how often migrants through Anaktuvuk interbreed with those moving through adjacent valleys.

In the years of recording numbers at Anaktuvuk (1950-65), we did not observe a large annual fluctuation in the number of willow ptarmigan. Referring to their memories and to the recollection of stories told by the old people, the Nunamiut estimated that from year to year the ptarmigan seen in one winter might have been one-third less than the number seen in another. An occasional large concentration of a moving population at a certain time and place favours chance single observations that may falsely indicate a fluctuation in number of the population. But we cannot see evidence at Anaktuvuk, a midpoint of migration, that would indicate annual changes in accordance with cyclic variations in the number of willow ptarmigan.

In 1964 the late spring migration was seen two weeks later than usual. In $1965-66$ the number of migrating ptarmigan seen was about one tenth of that seen in previous years, thus upsetting our earlier opinion about the numerical stability of the migrating population. In October and May at Anaktuvuk, the large, rapidly-moving migrating population may not be so correctly sampled and it is suspected that the less demonstrative female birds have not been sufficiently respresented in our earliest autumn and latest spring samples. 
The distribution of categories month by month in the north, middle, and southern areas of the range demonstrates a segregating process leading each category through its own temporal and spatial program. The general result appears in the progressive winter increase both of adult males in the north and of juvenile females in the south.

Robert Weeden (1964) has remarked on the winter segregation of Alaska rock ptarmigan (Lagopus mutus) that removes females to lower elevations while males remain at higher elevations. Willow ptarmigan (Lagopus lagopus) collected on the tundra during the winter, at timberline and higher, included more males than females. Winter segregation of sexes was indicated in relation to altitude, tundra, and forest.

The behaviour of ptarmigan in winter gives the impression that the birds are bound to gregarious activity. The associates in a flock move in concert while feeding, rest together at noon, and take wing and land together. In the evening, a flock of ptarmigan may suddenly descend in a group and land at spaced roosting places in the snow from which they do not move until morning. In the morning, they take wing together without walking from the roost, as their tracks show, and leave behind traces in the accumulated droppings of their overnight residence. It appears that in the day's activity, association in a flock regulates many individual actions.

In spite of this appearance of coherent behaviour throughout the winter, the changing composition of flocks shows that each category pursues its own independent schedule. In early and late winter, component categories in flocks at each locality change proportions rapidly, and associations in flocks must be transitory. Even in winter, special impulses characteristic of sex and age lead the ptarmigan of each category through a spatial and temporal program under influences different from those that keep flocks in the temporary coherence seen during brief observation.

If we start at Umiat, a centre in the nesting area, the small sample in September has about an equal number of the two sexes; this may have come about as a result of the assembly of local broods. But in October, the categories in the flocks are already very unequal; this can only have been caused by differential immigration and emigration of the categories. At present, we cannot see how seasonal changes in the composition of the flocks of ptarmigan in any given locality can occur without selective detachment from the flocks by birds of each category to move in their own spatial and temporal program.

The area through which these willow ptarmigan migrate is little inhabited and scarcely disturbed by man. Segregation of component categories in the population distributes the birds over a long distance, though not uniformly in time and space. Each category seems to relate its particular program to time and place. The willow ptarmigan are the largest bird populations visible on the arctic tundra; they have been successful for many years in this region of cold and violent storms, subsisting on a food supply that is restricted to a few species of willow growing sparsely on an otherwise barren land. According to observation, this is due to the organization of 
the population, an organization which ensures, through effective distribution of the birds, that the most efficient use is made of their environment.

\section{ACKNOWLEDGEMENTS}

Garlyn R. Warren programmed and analyzed all data; Martha S. Meng and Susan Savage aged and sexed collected birds. In addition to several residents at Anaktuvuk, Wallace Nictune, William Fickus, Wendall Wassmann, Thomas Dean, and Paul Fleischer helped in collecting birds.

The work was supported in part by National Institutes of Health Grant GM10402, and logistic support was received from The Arctic Research Laboratory at Barrow, Alaska.

\section{REFERENCES}

IRving, Laurence, ig6o. Birds of Anaktuvuk Pass, Kobuk, and Old Crow: a study in Arctic adaptation. U.S. National Museum Bulletin No. 21 7. Washington, D.C.

irving, LaURence, george C. West, and leonard J. Peyton, 1967. Winter Feeding Program of Alaska Willow Ptarmigan Shown by Crop Contents. Condor, 69: 69-77.

WEEDen, ROBERT B., I964. Spatial Separation of Sexes in Rock and Willow Ptarmigan in Winter. Auk, 81: 534-41.

West, george c., and martha s. Meng, ig66. Nutrition of Willow Ptarmigan in Northern Alaska. $A u k, 83: 603-15$.

WeSt, GEORge C., GARLYN R. WARREN, LAURENCE IRVING, and LeONARD J. PEyton (in press). Morphological Homogeneity of a Population of Alaska Willow Ptarmigan. Condor. 


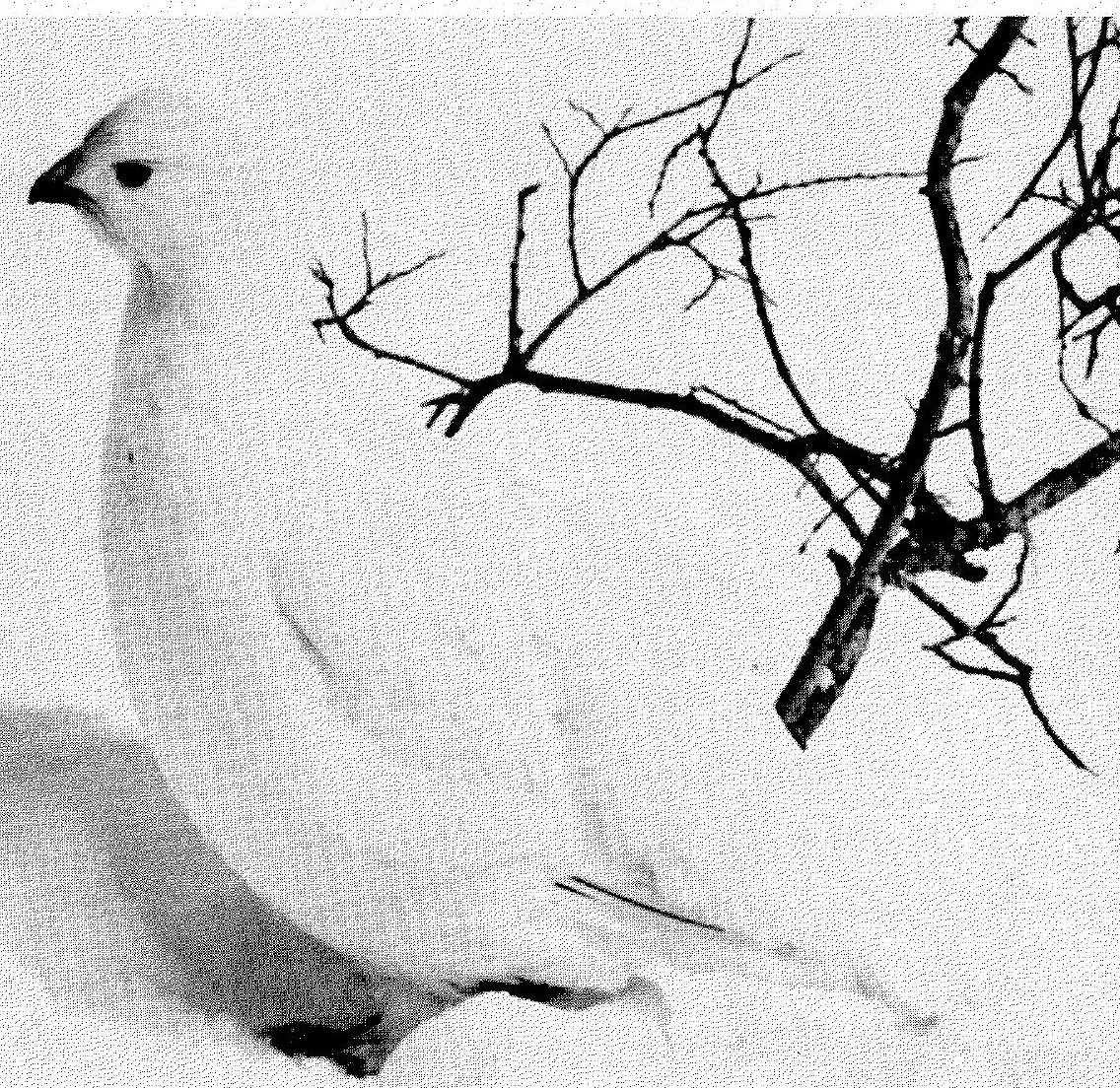

Alaska Willow Ptarmigan in Winter Plumage 